\title{
The development of cave passage in Donomulyo, Malang-Indonesia
}

\author{
Mohammad Ainul Labib ${ }^{1, *}$, Eko Haryono², and Sunarto ${ }^{2}$ \\ ${ }^{1}$ Master of Geography, Faculty of Geography, Universitas Gadjah Mada \\ ${ }^{2}$ Department of Environmental Geography, Faculty of Geography, Universitas Gadjah Mada
}

\begin{abstract}
The cave passages formed in Donomulyo sub-district are formed in epigenic and hypogenic conditions in coastal areas. The dominant factors form the morphological condition of the cave passage that is the existence of structural factors, underground water flow, and tectonism that affect the condition of the passage. Structural factors form the existence of linement that affect the cave passage. Underground water flow forms a passage due to the change of vadose, epipreatic, and phreatic conditions. The existence of tectonism leads to the removal of limestone into several levels of cave passage development, in addition, there is the collapse of blocks, plates, talus, and sheets. The development of the cave passage level is also related to surface physiographic, which is connected to 5 levels with marine terrace, including 244-325 masl (level 1), 182-244 masl (level 2), 111-181 masl (level 3), 30-110 masl (level 4), and 0-29 masl (level 5). The development of fifth level shows that the level limit is located in the Sengik Cave, the fourth level is located in the Jebrot Cave, and the second level is located in the Banyu Cave, these three caves are the output of the underground rivers.
\end{abstract}

\section{Introduction}

The physiology of the southern java mountains stretches from Yogyakarta to the western part of Blambangan in the eastern tip of East Java. The appearance of the plateau formation was a result of the uplifted peneplain on the miocene period [1]. As a result of the lifting process, the limestone sediment that interspersed with volcanic rocks in the sea rose into the mountains. Donomulyo sub-district is located in the southern java mountains (Figure 1), which was composed of Wonosari formation in the form of coral limestone, silty limestone, tuffling limestone, sandy limestone, marl, peaty black clay and calcirudite. The age of Wonosari formation is in middle miocene-late miocene. The Wonosari formation overlaps the Campurdarat formation and other old rock units. The thickness of this rock unit is around $80 \mathrm{~m}$ and $200 \mathrm{~m}$ [2]. Lifting and folding may occur again in PlioPliotosen, followed by a process of denudation. This tectonic activity only resulted in tilting the Wonosari Formation to the south with $10^{\circ}$ inclination angle [3].

The existence of caves in Donomulyo sub-district of the southern part of Malang regency has a vertical and horizontal cave passage. The caves can create unified systems and isolated caves [4]. The availability of the passage can provide an overview of endokarst morphology conditions. These conditions provide a level in cave development. In addition, the the cave entrance height distribution can be used to identify the cave level, as the level pattern captures traces caused by tectonic and climate evolution. The occurrence of a horizontal passage on the cave is caused by hydrological factors, when the underground waterhas contact with the cave passage [5].

A cave is an endokarst appearance, which has a passage that is connected to the surface. The results of the cave entrance inventory show that the caves are spread in Donomulyo sub-district [6-11]. The formed cave is a natural opening which can be penetrated by human beings, as well as a channel for flowing water in it that can cause the dissolution of rocks and effective sediment transports in the drains [4], [12-13]. The purpose of this study is to illustrate the morphology of the cave passages and the development of the cave passages in the karst caves in Donomulyo sub-district, Malang regency.

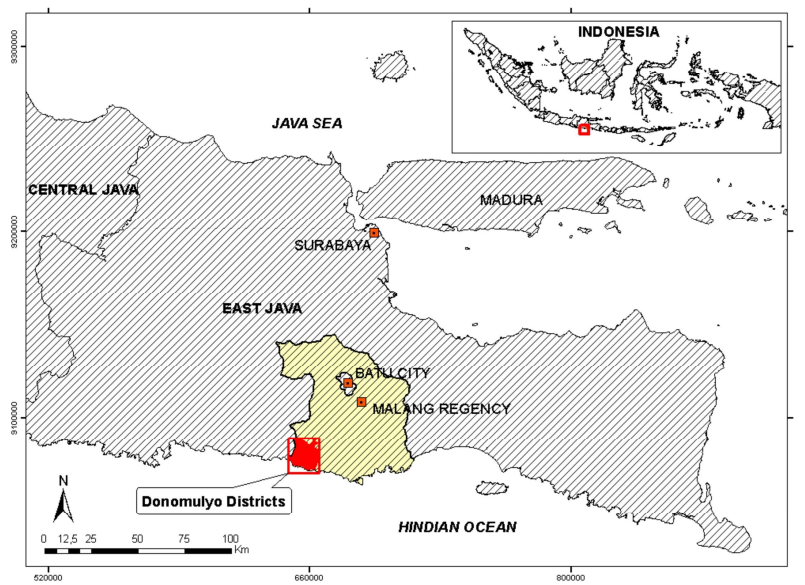

Fig 1. Location Donomulyo Sub-District, Malang Regency.

\footnotetext{
*Corresponding author: labib@mail.ugm.ac.id
} 


\section{Methods}

This research was conducted by using survey method. While the data collection was done during 5 months of 2015. Materials needed in this research were: Blitar and Turen geological map, SRTM image, cave passage map. On the other hand, the equipments used in this research were GPS, SRT Set, disto/roolmeter laser, compass, clinometer, tracing paper, brunton compass, polarization microscope

The selection of the research locations was in the form of caves located in Donomulyo sub-district of Malang regency. The cave in Donomulyo district had a population of 79 caves. Meanwhile, the consideration of cave selection was based on speleogenesis in the form of hypogenic cave and epigenic cave. The epigenic caves were cave that had been mapped previously, there were 16 caves (Banyu Cave, Sio Cave, Kerek Cave, Buntet Cave, Maron Cave, Bagus Cave, Tumang Cave, Kembar Cave, Megarsari Cave, Tekek Cave, Lowo Cave, Sumuran Cave, and Barong Cave). On the other hand, hypogenic cave was the cave close to the sea surface which was then mapped, there were 5 caves (Noname 1 Niche, Sengik Niche, Baron Niche, Glurug Niche and Patuk Niche). For morphometric analysis and cave passage level, the researcher used the caves that had been mapped previously.

Field data analysis consisted of spatial analysis, graphical analysis, morphometric analysis, morphological analysis of channels, petrographic analysis, and descriptive analysis. Spatial analysis was an analysis of space which was used to explain the spread of cave entrance in Donomulyo sub-district. This analysis was used to find out about the distribution of caves in the form of random, grouping, or uniform. Graphical analysis was used to describe the condition of the cave passage, to know the direction of the cave passage, and the description of the marine terrace development in Donomulyo sub-district. The morphometric analysis of caves (Table 1) can be used to determine the porosity variations found in caves, cave specific volumes, the density of cave passage ways, and cave area coverage, cave patterns, and to determine cave passage levels.

Morphological analysis of channels was used to describe the condition that existed within the cave, in the form of analysis of the existing form in the cave. This analysis allowed for characterization of past and present flow conditions in cave passages. Petrographic analysis was done by taking the rock sampling obtained at the time of the survey, then, it was analyzed. This analysis was used as a factor affecting morphological conditions of the cave. Characteristics of rocks were obtained based on laboratory observation using polarization microscope. Descriptive analysis was used to explain the conditions in the cave. This analysis was also used to explain the relationship of influencing factors in the development of cave passages associated with water flow, physiographic, lithologic, and geological structures.
Table 1. Cave passage morphometry [14-17].

\begin{tabular}{|c|c|c|}
\hline $\begin{array}{c}\text { Cave } \\
\text { Morphometry }\end{array}$ & Method & Symbol \\
\hline Cave Length & $\begin{array}{l}\text { Taken from the data by } \\
\text { using Survex software }\end{array}$ & $\mathrm{P}$ \\
\hline $\begin{array}{l}\text { Cave Area } \\
\text { Width (Es) }\end{array}$ & $\begin{array}{l}\text { Taken from the data by } \\
\text { using Survex software }\end{array}$ & $\mathrm{La}$ \\
\hline $\begin{array}{l}\text { Cave Area } \\
\text { Length }\end{array}$ & $\begin{array}{l}\text { Taken from the data by } \\
\text { using Survex software }\end{array}$ & $\mathrm{Pa}$ \\
\hline $\begin{array}{l}\text { Cave Depth } \\
(\mathrm{Rv})\end{array}$ & $\begin{array}{l}\text { Taken from the data by } \\
\text { using Survex software }\end{array}$ & $\mathrm{H}$ \\
\hline $\begin{array}{l}\text { The Area of } \\
\text { Cave Area }\end{array}$ & $\begin{array}{l}\text { Calculated from the width } \\
\text { and length of the cave area }\end{array}$ & $\mathrm{La}$ \\
\hline Cave Volume & $\begin{array}{l}\text { Taken from the data by } \\
\text { using Compass software }\end{array}$ & $\mathrm{V}$ \\
\hline $\begin{array}{l}\text { The Area of } \\
\text { Cave Passage }\end{array}$ & $\begin{array}{l}\text { Taken from the data by } \\
\text { using Compass software }\end{array}$ & $\mathrm{L}$ \\
\hline $\begin{array}{l}\text { Cave Rock } \\
\text { Volume }\end{array}$ & $\begin{array}{l}\text { Calculated from the width, } \\
\text { depth and length of the } \\
\text { cave area }\end{array}$ & $\mathrm{Vb}$ \\
\hline $\begin{array}{l}\text { Cave Specific } \\
\text { Volume }\end{array}$ & $\begin{array}{l}\text { Calculated from cave } \\
\text { volume and length }\end{array}$ & Vs \\
\hline $\begin{array}{l}\text { Cave Passage } \\
\text { Density }\end{array}$ & $\begin{array}{l}\text { Calculated from the } \\
\text { passage length and the } \\
\text { area of the cave }\left(\mathrm{Km} / \mathrm{Km}^{2}\right)\end{array}$ & Dl \\
\hline Cave Porosity & $\begin{array}{l}\text { Calculated from the cave } \\
\text { volume and rock volume } \\
(\%)\end{array}$ & $\mathrm{P}$ \\
\hline $\begin{array}{l}\text { Cave Area } \\
\text { Coverage }\end{array}$ & $\begin{array}{l}\text { Calculated from the area } \\
\text { of cave passage and the } \\
\text { area of the cave }\end{array}$ & $\mathrm{Ca}$ \\
\hline $\begin{array}{l}\text { Cave Passage } \\
\text { Sinousity }\end{array}$ & $\begin{array}{l}\text { The measurement was } \\
\text { done digitally by using } \\
\text { ArcGis } 10.2 \text { software }\end{array}$ & $\mathrm{S}$ \\
\hline \multicolumn{3}{|c|}{ Cave Morphometry Index Variables } \\
\hline Negative Drop & $\begin{array}{l}\text { The measurement was } \\
\text { done digitally by using } \\
\text { Survex software }\end{array}$ & Dn \\
\hline Positive Drop & $\begin{array}{l}\text { The measurement was } \\
\text { done digitally by using } \\
\text { Survex software }\end{array}$ & $\mathrm{Dp}$ \\
\hline Real Length & $\begin{array}{l}\text { Taken from the data by } \\
\text { using Survex software }\end{array}$ & $\mathrm{Lr}$ \\
\hline Plan Length & $\begin{array}{l}\text { Taken from the data by } \\
\text { using Survex software }\end{array}$ & $\mathrm{Lp}$ \\
\hline Extension & $\begin{array}{l}\text { The measurement was } \\
\text { done digitally by using } \\
\text { ArcGis } 10.2 \text { software }\end{array}$ & Ex \\
\hline $\begin{array}{l}\text { Verticality } \\
\text { Index }\end{array}$ & $\begin{array}{l}\text { Calculated from Rv and } \mathrm{Lr} \\
\text { Data }\end{array}$ & $\mathrm{R}_{\mathrm{v}} / \mathrm{L}_{\mathrm{r}}$ \\
\hline $\begin{array}{l}\text { Horizontality } \\
\text { Index }\end{array}$ & $\begin{array}{l}\text { Calculated from Lp and Lr } \\
\text { Data }\end{array}$ & $\mathrm{L}_{\mathrm{p}} / \mathrm{L}_{\mathrm{r}}$ \\
\hline Linearity Index & $\begin{array}{l}\text { Calculated from Rv, Ex } \\
\text { and Lr Data }\end{array}$ & $\frac{\sqrt{\mathrm{Ex}^{2}-\mathrm{Bv}^{2}}}{\mathrm{~L}}$ \\
\hline $\begin{array}{l}\text { Horizontal } \\
\text { Compexity } \\
\text { Index }\end{array}$ & $\begin{array}{l}\text { Calculated from Lp and Es } \\
\text { Data }\end{array}$ & $\mathrm{L}_{\mathrm{p}} / \mathrm{E}_{\mathrm{s}}$ \\
\hline \multicolumn{3}{|c|}{ Chamber Type/Maze Cave } \\
\hline Mean Width & $\begin{array}{l}\text { Calculated from Cave } \\
\text { Area that was divided by } \\
\text { Cave Length }\end{array}$ & Mw \\
\hline Lenght/Width & $\begin{array}{l}\text { Calculated from Cave } \\
\text { Length Ratio that was } \\
\text { divided by Mean Width }\end{array}$ & $L / W$ \\
\hline
\end{tabular}




\section{Results and discussions}

\subsection{Distribution of caves in Donomulyo}

The distribution of cave entrance had a grouping pattern, it can be seen from the calculation value of distribution index of 0.456 which showed that the distribution of the cave was in a grouping pattern. From these results, the caves located in Donomulyo sub-district can have caving system and underground flow system. This flow system was found in the Banyu Cave system (Figure 2) as the output of underground water. The passages that formed the caving system were found in Bagus-Jebrot Cave, Megarsari Cave, Lowo Cave, which had two cave connected entrances. Whereas, the other caves can be in the form of isolated caves, which existence was not connected with the other systems.

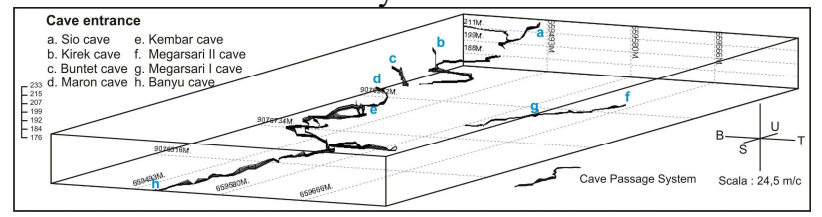

Fig. 2. The underground water flow system in Banyu Cave.

\subsection{Speleomorphology of karst caves}

The cave passage can be seen from: cave entrance, cave passage, cave room, vertical passage, micro formations, breakdown, cave ornament, and cave cross section. The formation of cave entrances was caused by the presence of major or minor cracks that drain the surface flow into the cracks, the presence of cracks on the cave roof, as well as the existence of the wave power that formed the overdraft around the coast. The cave passage pattern can be seen from the top-visible map which showed the formation of single passage. Cave passage pattern (Figure 2) was branched in the field of erosion and perpendicular to the presence of cracks by having inputs of doline and submerged rivers.

The cave room in the reserach location occurred due to the intersection of several cave passages, if there was a passage dominated by a narrow passage, a collapse process that resulted in passage widening, and anencounter of vertical passage with horizontal passage. On the other hand, the appearance of the vertical passage (Figure 3) developed due to the collapse of the cave roof, formed in the valley/doline, the existence of lifting formed the cave passage levels, and vertical passage formed the main passage as the cave entrance.

The cave passage profile (Figure 4) showed the development of the passagein the past. The elliptical form of the passage indicated the presence of a stream that eroded the passage. The formation which was located in vadose zone was in the form of developed passage with the existence of the ruins, in addition, thechange of surface ground water and the flow of the cave passage will result in a micro formation of pocket, scallops, cupolas, potholes, solutions notch, rill cave, pendant, anastomoses, and meandering conduit. In addition, it will be followed by the development of ruins in the form of blocks, plates, talus, and sheets. Cave ornaments consisted of pillars, stalactites, stalagmites, conical stalactites, moonmilk stalactites, flowstones, canopies, shawls, microgourdams, and gourdams.

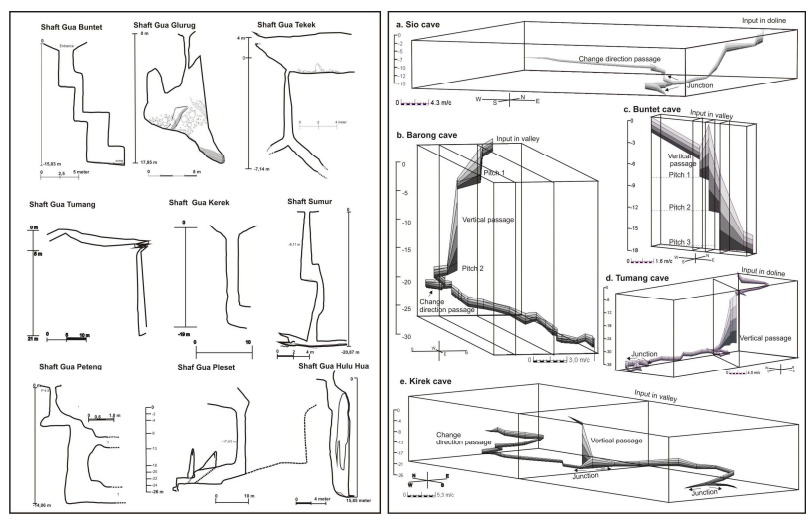

Fig. 3. The development of vertical passage (a) and the cave passage pattern (b).

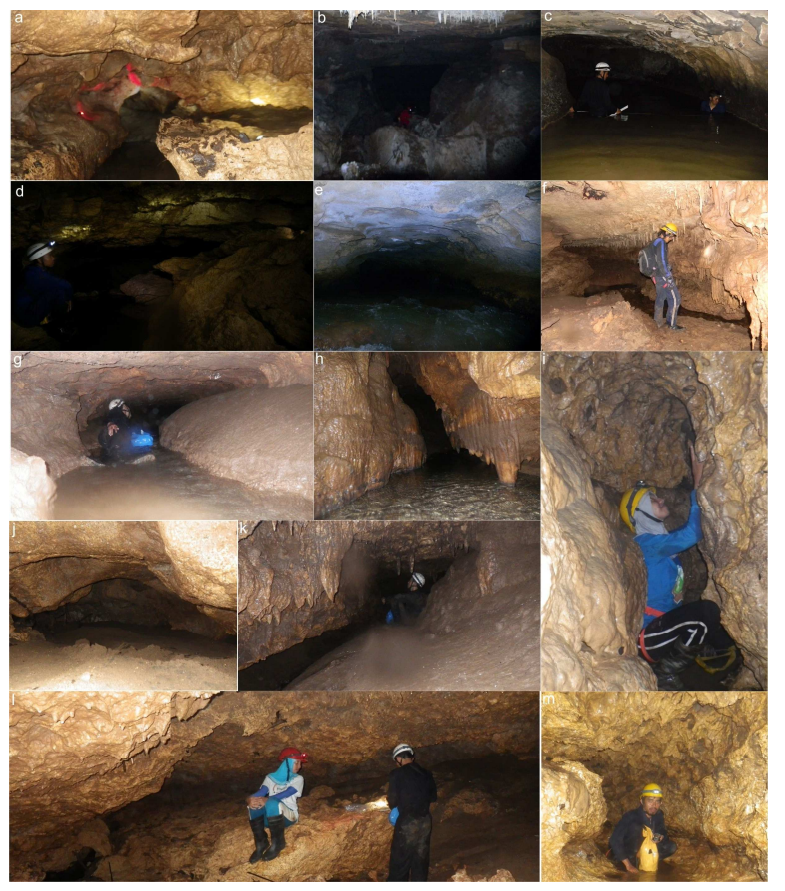

Fig. 4. The cave passage profile, controlled by structural (a, f, $\mathrm{h}, \mathrm{i}, \mathrm{j}, \mathrm{l}$, and $\mathrm{m}$ ) and hydraulic (c, e, k, and $\mathrm{g}$ ), and root cave collapse growing ( $b$ and $d$ ).

Cave morphometry was used to identify the development of the passages under the pressed or unpressed conditions. Figure 5 showed three parameters, namely: porosity, area coverage, and passage density. Caves that had vertical passage shape had a considerable value to these three parameters, but the development of the cave passage had not progressed to a pressed aquifer, but had developed in a free aquifer. This can be seen from the existence of cave ornaments that developed on the vertical passage wall, which provided an explanation that the flow formed was in the form of meteoric water flow. In addition, the vertical passage had a similarity in terms of cave lengths of $<50 \mathrm{~m}$, this was because the passages formed were caused by structural processes that occurred in the research location and the passage stopped 
in the presence of cracks or in the form of seepage flow was difficult to enter by human, so that the cave passage only had a short main passage.

The other cave passage conditions showed a value below the average value of the aquifer parameters. It occurred because the caves which underwent a development and were mapped in the research location had an uncomplicated cave passage, in the form of main passages that had a branching level of diffuse / fissure, and there was still rarely found a branching in the form of conduit.

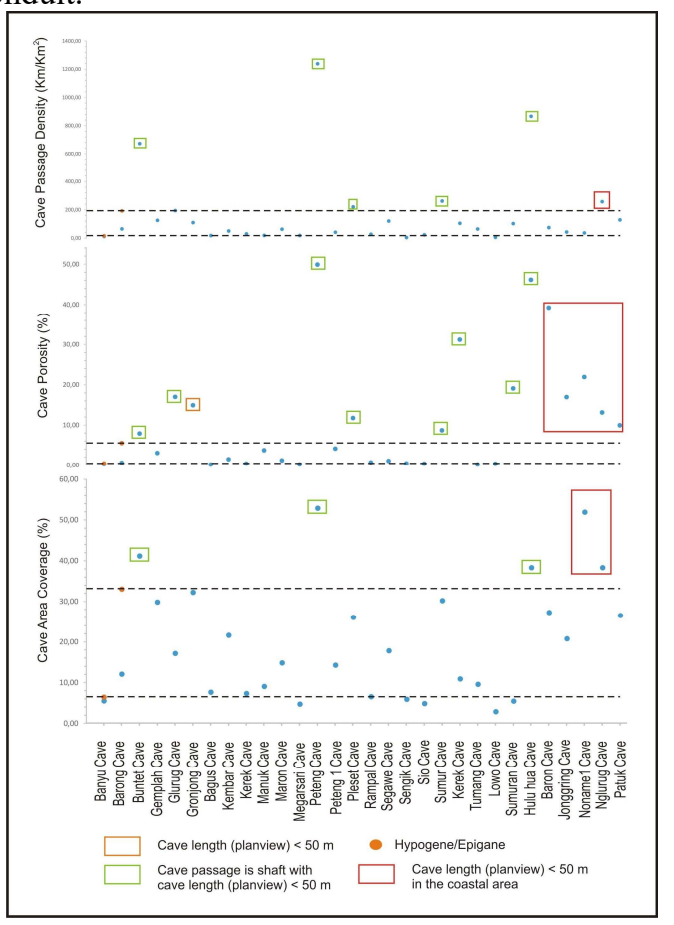

Fig. 5. The morphometry of cave passage.

The morphometry of the cave was related to the sinousitas of the passage (Figure 6 (a)), from the results of the top-visible cave map analysis, it appearred that there were similarities among the caves. This similaritieswere in the form of a straight-passage and winding (meandering) passage. Straight passages were located in the passages that formed a vertical passage located in the Sumuran Cave, Buntet Cave, Glurug Cave, Hulu Hua Cave which was controlled by a structural process in the form of cave passage deflection. The winding passage was formed in a cave passage that had underground water level which was proportional to sea level, which then followed the existing rock layering fields. It was seen in Tumang, Bagus, and Sengik Cave. Banyu Cave also developed a winding passage, this can be seen from the bending value of $>3$ which gave an idea of the condition of the Banyu Cave in the past, which occurred on underground water conditions.

Other calculations of formations were related to space and labyrinth (Figure 6 (b)). The cave that had a labyrinth was found in Bagus Cave, although the value was still very small, nearly of $>20$. Caves that had large passage lengths can not form a labyrinth cave because of the extent of the cave passage, this was seen in Tumang Cave $\left(17.33 \mathrm{~m} \cdot \mathrm{m}^{-1}\right)$, Peset Cave $\left(14.24 \mathrm{~m} \cdot \mathrm{m}^{-1}\right)$, Segawe Cave $\left(11.44 \mathrm{~m} \cdot \mathrm{m}^{-1}\right)$ which hada small area.
Meanwhile, Bagus Cave formed a labyrinth because the width of the cave area was covered in the cave passage which provided a level of complexity in the cave passage. However, the value of $23.83 \mathrm{~m} \cdot \mathrm{m}^{-1}$ was not too complicated that was formed in the Bagus Cave passage

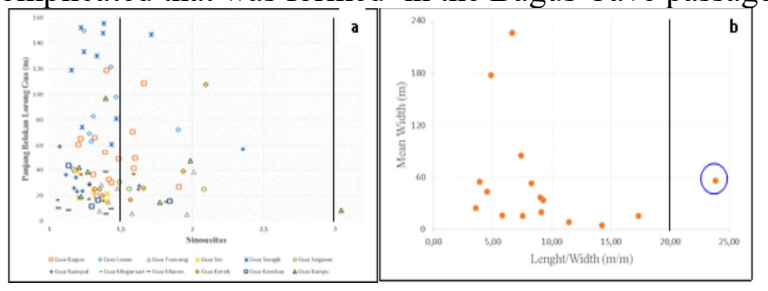

Fig. 6. The sinousitas of cave passage (a) and the type of cave passage (b).

\subsection{Development karst in cave passage level}

The vertical axis formed developed on each stratigraphic section, it was seen from Figure 7 which showed the altitude distribution with the length frequency of the cave passage. Vertical passage was formed with different altitudes, such as in Glurug Cave (38 masl), Hulu Hua Cave (55 masl), Sumuran Cave (88 masl), Buntet Cave (209 masl), Peteng Cave (134 masl), and Sumur Cave (267 masl). Horizontal cave passages had uniform distribution at nearly the same height. This distribution was the result of a cave passage developing in the field of rock bedding. This horizontal passage can develop in the phreatic and vadose conditions that develop in the plating field. Horizontal cave passage in vadose condition (Megarsari Cave, Maron Cave) had a short cave length compared to phreatic conditions (Sengik Cave, Bagus Cave, Banyu Cave, and Lowo Cave). The distribution of passages that had the longest graph was the beginning of the horizontal passage development, the appearance was seen in Manuk Cave, Banyu Cave, Bagus Cave, and Sengik Cave.

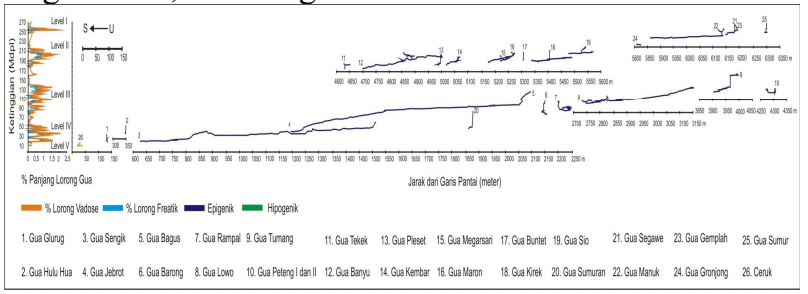

Fig. 7. The altitude distribution, level and profile of cave passage in Donomulyo Sub-District.

Figure 8 showed the existence of cave morphometric index in the form of horizontal, vertical, linearity, and horizontal complexity index. The horizontal index in the cave passage which was close to 1 was in a niche around the coast, in addition, the appearance of horizontal cave passages also had high horizontal index values such as Kembar Cave, Maron Cave, Gronjong Cave, Banyu Cave, Lowo Cave, and Sio Cave (ranged from 0.940.99). It was due to the structural control that governed the horizontal pattern of the cave; in addition, the development of the cave passage was related to the development of passages along the underground water level, as developed in Bagus Cave and Banyu Cave. 
The vertical index which had a value close to 1 , was a vertical passage in the absence of a horizontal passage. The highest vertical index wasfound in the Hulu Hua cave (0.76), Sumuran Cave (0.74), and Peteng Cave (0.72). The three caves, growing vertical passage from the cave entrance, but there was a large room so that the value of the vertical index was not up to 0.9 . The development of this passage indicated the existence of geological structural factors in the form of a sturdy, fault, and cracks. The linearity index of the cave showed the development of a straight line, vertical, oblique or horizontal pattern. The cave that had a straight passage indicated that the cave developed in a horizontal passage field. This was seen in coastal niches and in Gronjong Cave. Bagus Cave had the highest index of horizontal complexity than the other caves, this cave developed along the passage of the underground water level and there was a vertical axis under vadose condition that connected downward in one main link to form a caving system.

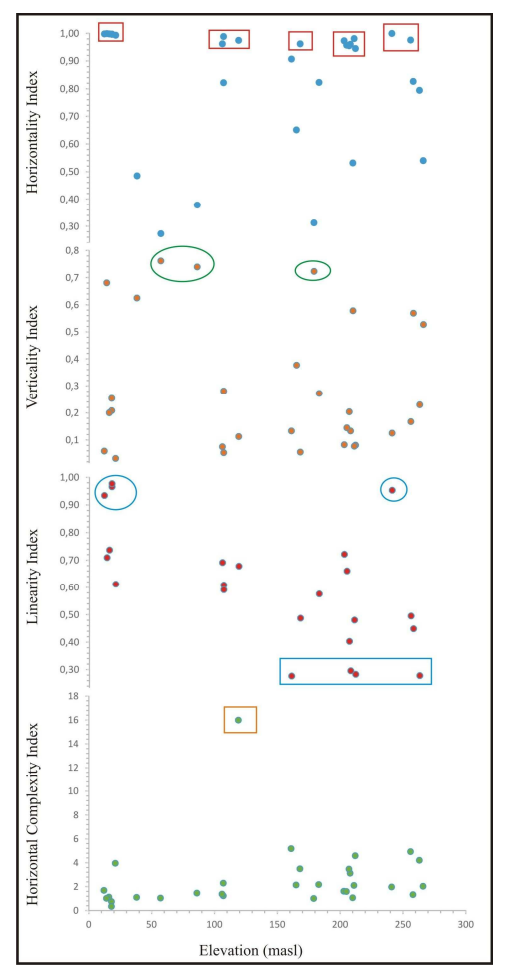

Fig. 8. The relationship of altitude with morphometry.

The result of inner edge profile interpretation indicated the degree associated with the existence of the cave passage level, which had 5 levels in the development of the cave passage (Figure 9). The marine terrace level had a height of 244-325 masl (level 1), 182-244 masl (level 2), 111-181 masl (level 3), 30-110 masl (level 4), and 0-29 masl (level 5) . The first level, the frequency of the cave passage level was found in Segawe Cave and Manuk Cave. The second level, there was an output from the passage of Banyu Cave (176 masl), with the existence of undergroundflow system from several caves. The third level showed the development of horizontal passages, located in the Lowo Cave (114 masl) and there was a horizontal passage after the vertical passage in Tumang Cave. The fourth level, there was an output of Bagus Cave (43 masl), which indicated the existence of underground waterflow. The passage developed throughout the plating field. The fifth level was found in Sengik Cave (22 masl), which showed horizontal passages and a niche around the coast indicating that there was a contact between underground water with sea water.

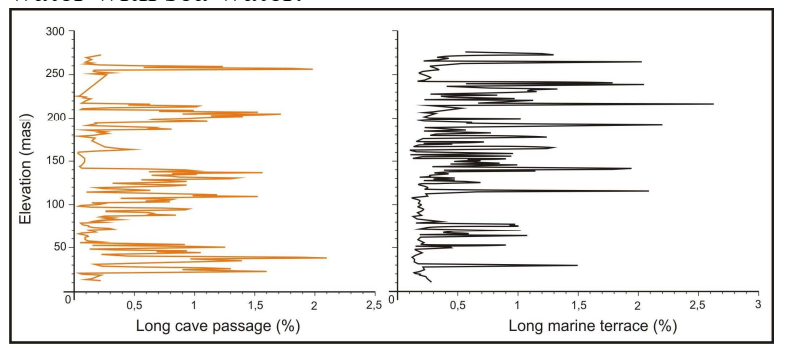

Fig. 9. The relationship of marine terrace with cave passage length.

\subsection{The development of karst cave passage}

Speleogenesis was a process that influenced the origin and development of the natural underground cavity. Donomulyo sub-district was a sediment of shallow sea, it was seen from the existence of rock types (wackestone, boundstone, and packstone) which described the deposition of carbonate rocks. The rocks which underwent karstification formed a karst natural stretch.

The process of tectonism that influenced the formation and development of the cave was the result of the lifting. This process resulted in a change of underground water level in the area. In the caving system, there was a change in the existence of the stratified cave passages. The southern part of Malang Karst Zone was located in the southern mountainous zone. Karst morphology developed in the research area was in the form of fluviokarst formation. This formation was dominated by bulging fluvial formation, than by the solusional formation by the presence of perennial rivers in the research locations.

The results of the morphological straightness orientation analysis located around the cave passage and the cave passage direction used a rose diagram. The results showed that caves in research locations had the south direction dominance, while the mean direction of the cave passage had different directions. Bagus Cave $\left(\mathrm{N} 177.8^{\circ} \mathrm{E}\right)$, Tumang Cave (N 170.8 $\left.{ }^{\circ} \mathrm{E}\right)$, Manuk Cave (N $\left.180.8^{\circ} \mathrm{E}\right)$, and Sengik Cave $\left(192.7^{\circ} \mathrm{E}\right)$ had a tendency to the south, Lowo Cave (N 214.6 $\left.{ }^{\circ} \mathrm{E}\right)$ and Banyu Cave (N 203.3 ${ }^{\circ}$ E) had a tendency to the south southwest. On the other hand, Rampal Cave (N 262.9 $\left.{ }^{\circ} \mathrm{E}\right)$ and Megarsari Cave (N 232.7 $\mathrm{E}$ ) led to the west and southwest. The direction of the passage cave had similarity with the direction of the morphological straightness around the cave.

This speleogenesis analysis was related from direct observation of the caves that had been traced before. There was a level in the development of the cave, Level I, the formation of karst morphology occurred in the Pleistocene, which waspreceded by the reef or coral sedimentation to the surface which was caused by the 
lifting process. Level II, there was a tectonism process in the form of lifting. This process resulted in a decrease in underground water level and in the previous lifting of phreatic conditions into vadose conditions. Level III, the southern mountains of Java Island experienced considerable lifting intensity [18].

Levels IV, collapse and dissolution process continued to occur in the previous levels. The underground surface water changedin deeper manner. The development of the passage was dominated by the dissolution process in the layering area. The process of widening the passage occurred intensively horizontally, so there wasa winding pattern in the cave passage, especially in the main cave passage of the underground river. Level $\mathrm{V}$ was a passage that developed in the area of the coast. At this level, there was a cave passage that had contact between limestone with sea water exposed to the surface and the flow of the ground river connected to the surface river.

The results of the study of cave level in Donomulyo sub-district, and related to river terrace showed the existence of 5 levels of morphological development of cave passage located in Donomulyo sub-district, Malang regency. The development of karst area found in the southern mountainous area of Java Island had a different profile. The results of the study in Blambangan Peninsula Karst showed the existence of 3 marine terraces [19] In Gunungsewu Karst, there were three terraces viewed from the marine terrace, paleocave level, and river terraces [20]. The results of identification with satellite images also indicated the existence of 3 marine terraces [21]. At Gunungsewu Karst in Pacitan district showed 5 terraces on the eastern side of Pacitan Bay [22]. The development of Karangbolong Karst showed the development of 4 to 5 terraces by showing the presence of cave passages and the presence of subsoil [23]. The development of the terrace at Pacitan Bay and Karangbolong Karst had the same terrace profile as Karst in Donomulyo sub-district.

\section{Conclusion}

The development of the cave passagewas formed in areas with free-aquifer. The cave passage formed a morphology in the form of elliptical passages and gorges that were accompanied by rubble, this was seen from cross section calculations which showed that the cave passage formed due to structural and hydraulic processes occurring in various cave passages. The cave morphometric index showed that the cave passage in Donomulyo Sub-District had horizontal, vertical, or complex caves. The profile of the cave passage between one and the other showed the same pattern of passage level development, which was in vadose and phreatic conditions. In addition, there were terraces that had the same appearance with the horizontal cave passage on the surface, indicating a similar relationship in the development of endocarst and exocarst regions. The development of the cave passage is connected to 5 levels with marine terrace, including 244-325 masl (level 1), 182-244 masl (level 2), 111-181 masl (level 3), 30-110 masl (level 4), and 0-29 masl (level 5).
Authors would like to thank IMPALA UB and MPA Jonggring Salaka UM for data source and data collection. Authors would also like to thank all parties involved in the research.

\section{References}

1. A.J. Pannekoek, Garis-garis Besar Geomorfologi Pulau Jawa (1949)

2. M.Z. Sjarifudin, S. Hamidi, Geologi Lembar Blitar, Jawa (1992)

3. Suyanto, R. Hadisantono, Kusnama, R. Chaniago, R Bahruddin, Geologi Lembar Turen, Jawa (1992)

4. D. Ford, P. Williams, Karst Hydrogeology and Geomophology (2007)

5. L. Piccini, Recent Developments on Morphometric Analysis of Karst Caves 43-52 (2011)

6. Perum Perhutani, Inventarisasi Dan Pemetaan Lokasi Mulut Gua (1997)

7. A. Wicaksono, Pemetaan dan Eksplorasi Gua Bagus (2004)

8. S. Efendi, L. Pratiwi, F.I. Rustiana, Penelusuran Gua Rampal (2011)

9. Impala UB, Studi Potensi Kawasan Karst Di Desa Kedungsalam, Kecamatan Donomulyo (2013)

10. M.A. Labib, Karakteristik Morfologi Lorong Sistem Perguaan Bagus-Jebrot (2012)

11. A. Suprianto, Pendataan Sungai Bawahtanah di Gua Bagus-Jebrot untuk Sumberdaya Air Kawasan Karst (2013)

12. D. Gellieson, Caves: Processes, Deve lopment, and Management (1996)

13. A. Klimchouk, Caves In: J. Gunn, Encyclopedia of Caves and karst Science (2003)

14. A. Klimchouk, Unconfined Versus Confined Speleogenetic Settings: Variations of Solution Porosity (2006)

15. E.P. Iguzquiza, J.J.D. Valsero, V.R. Galiano. Morphometric Analysis of Three-Dimensional Networks of Karst Conduits (2011)

16. L. Piccini, Recent Developments on Morphometric Analysis of Karst Caves 43-52 (2011)

17. A. Frumkin, I. Fischhendler, Morphometry and Distribution of Isolated Caves as a Guide for Phreatic and Confined Paleohydrological Conditions 457-471 (2005)

18. R.W. Bemmelen, The Geology of Indonesia 2 (1949)

19. E. Haryono, Uplift Evidence From karst Morphology: Preliminary Evidence From Blambangan Peninsula Karst, Indonesia (2013)

20. Urushibara, K. Yoshino, Environmental change in the Karst Areas on the Island of Java (1997)

21. E. Haryono, Suratman, Significant Features of Gunung Sewu Karst As Geopark Site (2010)

22. H.D Tjia, Morphostructural Development of Gunungsewu Karst, Jawa Island Indonesian (2013) 
23. E. Haryono, T,P. Sutanto, F. Nuchfera, B. Yulianto, Karst Morphology and Hydrogeology of Karangbolong Area, Indonesia (2014) 